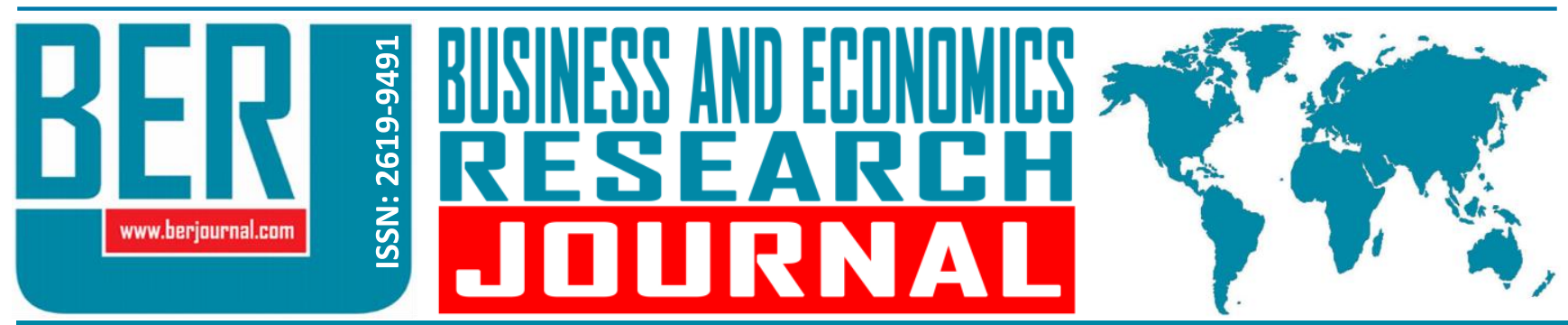

Business and Economics Research Journal Vol. 10, No.4, 2019, pp. 1005-1013 doi: 10.20409/berj.2019.216

\title{
İşyerlerinde Engelli Erişimi: Türkiye Üzerine Bir Araştırma ${ }^{1}$
}

\author{
Serpil Kahraman ${ }^{\mathrm{a}}$, Cagrı Bulut ${ }^{\mathrm{b}}$, Erhan Aydin ${ }^{\mathrm{c}}$
}

Öz: Iktisadi kalkınma politikaları, işgücü piyasasında engelli bireylerin entegrasyonunun arttırılması gereğini belirtmektedir. Söz konusu politika aracında, engelli erişilebilirliğinin sağlanması temel koşuldur. Erişilebilirlik kavramı, yalnızca fiziki altyapı erişimini değil aynı zamanda işe erişim, işgücüne katılım ve istihdam sonrasındaki destek araçları, esnek iş modeli, korumalı işyeri gibi politikalar ve makul düzenlemeleri de ifade etmektedir. Çalışma kapsamında, Türkiye'de 20 farklı kamu ve özel sektör kurumlarından engelli bireyleri de kapsayan, işveren ve çalışanlarla birebir görüşmeler yoluyla işyerinde engelli erişilebilirliğine yönelik algı/farkındalık ile mevcut uygulamaların tespiti amaçlanmaktadır. Bulgular, konuya ilişkin bilgi düzeyi yetersizliğinin, erişim ve iletişim yetersizliklerinin engelli erişilebilirliğinin önünde bariyer teşkil ettiğini ortaya koymaktadır.

Anahtar Sözcükler: Engellilik, İstihdam, İşgücü Piyasası

JEL: J70, J64

$\begin{array}{ll}\text { Geliş } & : 22 \text { Mart } 2019 \\ \text { Düzeltme } & : 15 \text { Mayıs } 2019 \\ \text { Kabul } & : \text { 31 Mayıs } 2019 \\ \text { Tür } & : \text { Araştırma }\end{array}$

\section{Disability-Accessibility at Workplace: A Research from} Turkey

Abstract: Economic development policies indicate the need to increase the integration of people with disabilities in the labor market. In this policy instrument, the provision of disabled accessibility is a key condition. Accessibility not only means access to physical infrastructure, but also access to employment, labor force participation and postemployment support tools and policies such as flexible business model, protected workplace, and reasonable adaptations. The aim of this study is to present the perceptions and practices of organizations towards the employment and accessibility aspects in the Turkish context. For this aim of the study, interviews are made with the representatives of 20 different public and private sector organizations. The findings indicate that the lack of knowledge, accessibility, and communication are the main barriers to disabled accessibility.
Keywords: Disability, Employment, Labour Market

JEL: J70, J64

$\begin{array}{ll}\text { Received } & : 22 \text { March } 2019 \\ \text { Revised } & : 15 \text { May } 2019 \\ \text { Accepted } & : 31 \text { May } 2019 \\ \text { Type } & \text { : Research }\end{array}$

Asst.Prof., PhD., Yasar University, Faculty of Business Administration, Department of Economics, Izmir, Turkiye, serpil.kahraman@yasar.edu.tr (ORCID ID: 0000-0003-4570-1604)

b Assoc. Prof., PhD., Yasar University, Faculty of Business Administration, Department of Business Administration, Izmir, Turkiye, cagri.bulut@yasar.edu.tr (ORCID ID: 0000-0002-3291-673X)

Asst. Prof., PhD., Usak University, Faculty of Economics and Administrative Sciences, Department of Business Administration, Usak, Turkiye, erhanaydin.phd@gmail.com (ORCID ID: 0000-0003-2530-9058) 


\section{Giriş}

Engelli bireylerin, istihdam oranlarının arttırıması, ekonomik kalkınmanın temel hedeflerinden biridir. Ancak, yasal ve yapısal düzenlemelerin mevcut olduğu ve işgücü piyasasının çok çeşitli seçenekler sunduğu gelişmiş ülkelerde bile, hedeflenen engelli istihdam düzeyine ulaşılamamıştır. BM (Birleşmiş Milletler) verilerine (2011) göre, engelli nüfusu, dünya nüfusunun yaklaşık \%10-12'sini oluşturmaktadır. Toplam engelli nüfusun yaklaşık \%80'i ise düşük gelir grubunda yer alan ülkelerde yaşamaktadır. Türkiye'de ise bu oran \%77,1'dir. Yoksulluk sınırının altındaki bir birey, özellikle eğitim, sağlık ve istihdam olmak üzere ekonomik, sosyal ve insan haklarını esas alan unsurlara erişim kısıtı altındadır. Bu doğrultuda işsizlik, engellilerin yoksulluk sınırının altında olmasının en önemli nedenlerinden biri olarak öne çıkmaktadır. Dünya Bankası, engellilerin işgücü piyasasına aktif katılımının milli gelirin yaklaşık \%5-7'sini teşkil ettiğini olduğunu belirtmektedir (Handicap International, 2006).

Türkiye İstatistik Kurumu'na (TÜiK) göre, Türkiye'de tahminen beş milyon engelli kişi (toplam nüfusun yaklaşık \%6,6'sı) yaşamakta olup, beş engelliden sadece biri işgücüne katılmaktadır $(\% 22,1)$. Ayrıca engellilerin \%63'ünden fazlası, yollar, kaldırımlar, binalar gibi fiziki alt yapı unsurlarında erişilebilirlik sorunu yaşamaktadır (TÜiK, 2011). Erişilebilirlik kavramı, ürün, hizmet ya da mekânların herkes tarafından ulaşılabilir ve kullanılabilir olmasını ifade etmektedir. Erişilebilirlik konusu, engellilerin iş piyasasına katılımının önündeki en büyük engellerden biridir. Bu veriler ışığında, bu çalışma, ülkelerin ekonomik kalkınması için önemli role sahip olan engelli bireylerin işyeri erişimine ilişkin algılarını ortaya koyarak onların deneyimledikleri zorlukları vurgulamayı amaçlamaktadır.

Çalışmamız kapsamında erişilebilirlik kavramı yalnızca fiziki alt yapı erişimini değil aynı zamanda işe erişim ve istihdam sürecinden sonra engelli bireye yönelik esnek çalışma saati, uyarlanmış iş gibi makul düzenlemeleri de ifade etmektedir. Türkiye'de işgücü piyasasında erişilebilirlikle ilgili ve farkındalık düzeyi ile engelli çalışanların işyerindeki durumu ortaya koymak çalışmanın temel amacını oluşturmaktadır. Bu doğrultuda, beş ilde ve farklı ölçeklerde faaliyet gösteren, kamu ve özel kuruluşlardan 20 temsilci ile yarı yapılandırılmış derinlemesine nitel görüşmeler gerçekleştirilen ve İçerik analizine dayanan araştırma kapsamında kartopu örneklem yöntemi uygulanmış olup, veri doyum noktasına ulaşıldığında görüşmeler sonlandırılmıştır. Çalışmanın giriş bölümünden sonra ikinci bölümde Türkiye emek piyasasında engelli istihdamına ilişkin genel bir bilgi, üçüncü bölümde konuya ilişkin literatür taraması, izleyen bölümlerde ise metodoloji ve bulgular açıklanmaktadır. Çalışma, sonuç bölümüyle tamamlanmaktadır.

\section{Türkiye Emek Piyasasında Engelli İstihdamı}

Türkiye Aile ve Sosyal Politikalar Bakanlığı, Engelli ve Yaşlı Hizmetleri Genel Müdürlüğü (EYH) tarafından 2011 yııında gerçekleştirilen "İ̧̧ücü Piyasasının Engellilik Perspektifinden Analizi" başlıklı çalışma engelli istihdamına ilişkin en kapsamlı çalışmalardan biridir. Dezavantajlı grup olarak engellilerin Türkiye'de işgücüne katılım oranı yaklaşık \%7 olup, bu oran erkek engellilerde \%35'in üzerinde iken, engelli kadın engellilerde ise \%6'ya düşmektedir (Türkiye Aile ve Sosyal Politikalar Bakanlığı, 2011).

2003 yılı 4857 Sayılı iş Kanunu'na göre, 50 ve daha fazla işçi çalıştıran kamu kurumlarında \%4, özel sektörde ise \%3 engelli iş̧̧i çalıştırma yasal zorunluluğu bulunmaktadır (4857 Sayılı iş Kanunu md.30).

Tablo 1. Türkiye'de Kamu Sektörü ve Özel Sektörde Engelli Başvuruları ve İ̧̧e Yerleştirmeler

\begin{tabular}{|c|c|c|c|c|}
\hline \multirow{2}{*}{ Yıllar } & \multirow{2}{*}{ Başvurular } & \multicolumn{3}{|c|}{ Yerleştirmeler } \\
\cline { 3 - 5 } & 76.235 & Kamu & Özel & $\%$ \\
\hline 2013 & 77.632 & 287 & 34.189 & 45 \\
2014 & 65.255 & 258 & 26.118 & 34 \\
2015 & 79.321 & 236 & 20.197 & 31 \\
2016 & 100.201 & 192 & 14.795 & 19 \\
2017 & & 11.959 & 12 \\
\hline
\end{tabular}

Kaynak: Türkiye İş Kurumu-ISKUR (2017). 
Tablo 1'de, Türkiye'de 2013-2017 yılları arasında engelli bireylerin iş başvuruları ile kamu ve özel sektörde işe yerleşme sayıları yer almaktadır. Bu doğrultuda, engelli bireylerin iş başvuruları 2015 yılı dışında artış gösterirken, istihdam oranları ise ele alınan dönemde yaklaşık \%33 azalmıştır. Kamu ve özel sektörde engellilerin istihdam durumu, kamu ve özel firmaların yoğunluğuna ve büyüklüğüne paralellik arz etmektedir.

Türkiye'de engelli işgücüne katılım oranını artırmak amacıyla kullanılan yöntemler kota yöntemi, rezervli istihdam yöntemi, vergi indirimi, teşvikler veya tazminat yöntemidir. En verimli yöntemin kota yöntemi olduğu görülmektedir (Yazıcı vd. , 2011). Türkiye Aile ve Sosyal Politikalar Bakanlığı'na (2011) göre kurumların engelli personel istihdam etmeme gerekçeleri \%48,5 kota kısıtı, \%31,5 sektörün engelli birey istihdamına uygun olmayışı ve \%11,6'sı ise engelli birey başvurusunun olmamasını göstermektedir. Diğer gerekçeler; iş kazası olasılığını arttırma, uyumsuzluk, iletişimde etkinsizlik, iş akışının yavaşlatma endişesi olarak sıralanmaktadır. Engelli birey istihdam etme nedenleri ise; \%66 yasal bir zorunluluk, \%24 sosyal sorumluluk ve \%10 işe uygunluktur. Söz konusu firmalar, engelli bireylerin çalışma azmi ve özverileriyle firmada performans artışına katkı sağladıklarını belirtmektedir (Türkiye Aile ve Sosyal Politikalar Bakanlığı, 2011).

Engelli bireyler istihdam süreçlerinde birçok bariyerle karşı karşıya kalmaktadır. Avrupa Komisyonu'na göre erişilebilirlik hedefleri, entegre çözümler, makul düzenlemeler, herkes için tasarım, çözümleri değerlendirmek için izleme, mimari yaklaşımlar ve uluslararası entegrasyon alanında işbirliğini kapsamaktadır (Avrupa Komisyonu, 2004). Eurostat (2014) raporuna göre bu engeller, \%34,7 işle ilgili kişisel veya çevresel sınırlamalar, \%29,5 uygun iş fırsatlarının eksikliği, \%19 aile ve işe geliş gidiş gibi taşıma sorumlulukları ile $\% 16,2$ engelli bireylerin nitelik ve deneyimlerinin görece yetersiz olmasıdır. Türkiye'de tüm bu faktörlerin yanı sıra ayrıca eğitim, engelli bireyin ikamet yeri, bireyin sosyal statüsü, sosyal ve tıbbi/rehabilitasyon hizmetlerine erişimin yetersizliği de bariyer istihdamı azaltan bariyerledir. Tüm bu kısıtlar nedeniyle, engelliler daha ziyade hizmet imalat sanayi vb. vasıfsı işlerde istihdam edilmektedir (Tufan vd. , 2007). Ayrıca ampirik çalışmalar engelli bireylerin işi ve eğitimi arasında bir korelasyon olmadığını ortaya koymaktadır.

\section{Literatür Taraması}

Engelli istihdamını kapsayan literatür oldukça sınırıdır. Birleşmiş Milletler'in 1988 yılında yayınladığı ve 55 ülkeyi kapsayan engelli veri tabanı (DISTAT) ilk uluslararası veri tabanıdır.

Papa ve Bambra (2005) 1990'dan 2002'ye kadar Genel Hanehalkı Verileri'ni kullanarak Engellilik Ayrımcılık Yasası'nın istihdam oranlarındaki rolünü araştırmaktadır. Engelli bireylerin istihdam durumlarının yasa öncesi ve yasa sonrasında karşılaştırarak, yasanın istihdama olumlu katkı sağladığını belirtmektedir. Duff, Ferguson ve Gilmore (2007), İngiltere'de insan kaynakları uzmanlarının, engelli kişilerin muhasebe firmalarında istihdamı ve istihdam edilebilirliği konusundaki tutumlarını incelemektedir. Firmaların engelli birey istihdamına engel teşkil eden faktörler ve firmaların engellilerin istihdam edilebilirliğine ilişkin algılarında bozulma olduğunu belirtmektedir. Shier, Graham ve Jone (2009) çalışmalarında, Kanada'da 20052006 istihdam eğitimi programlarına katılan 56 engelli ile görüşmeler gerçekleştirmiştir. Çalışma, erişilebilirlik, destek ağı eksikliği ve farkındalık gibi bariyerlerin engelleri azaltmada daha büyük bir etkiye sahip olduğunu ortaya koymaktadır. Peterson ve Quarstein'ın (2009) çalışmasında, işletme ve devlet kurumlarında engellilik bilinçlendirme eğitiminin bir analizi yer almaktadır. Gençler ve engelli genç yetişkinler için istihdamın önündeki engelleri araştıran bir başka saha araştırması ise Lindsay'in (2009) çalışmasıdır. Lindsay, gençlerin ve genç engelli yetişkinlerin işgücüne katılmak için daha fazla yardıma ihtiyaç duyduklarını ortaya koymaktadır. Robinson (2009), iki aşamalı analiz içeren çalışmasının ilk aşamasında, İngiltere'de faaliyet gösteren ve $20^{\prime}$ den fazla çalışanı olan 500 şirkete kısa bir anket iletmiş ve 126 şirketten yanıt almış olup, ikinci aşamada ise dokuz engelli bireyle yarı yapılandırılmış görüşme gerçekleştirmiştir. Bu çalışmanın bulguları, daha etkin iletişim araçlarına ve işverenler için etkin bir bilgi dağıtım stratejisine ihtiyaç duyulduğunu olduğunu göstermektedir. İşverenlerin farklı engel gruplarına göre istihdam edilebilirlik algılarını dikkate alan bir başka anket çalışması da Bricout ve Bentley (2010) tarafından yapılmıştır. İşe başvuru süreçlerinde engelli adayların yüksek ortalama istihdam edilebilirlik fırsatlarını elde edebildikleri sonucuna varmıştır. Kulkarni vd. (2016), dört katılımcıya yarı yapılandııımış görüşmeler yoluyla Hindistan ve 
Almanya'da faaliyet gösteren çok uluslu şirketlerde engelli çalışanların işyerine entegrasyonunu karşılaştırmalı olarak incelemişlerdir. Bulgular, özellikle örgütsel özellikler nedeniyle evrensel kabul gören ilkelerin uygulamada farklılaşabileceğini ortaya koymaktadır. Çalışmada ayrıca dış paydaş ve engelli bireylerle ilgili algının da ülkelerarası farklılık gösterdiği belirtilmektedir.

Türkiye'den engelli istihdamı konusunda sınırlı bir literatür bulunmaktadır. Tufan (2007) Türkiye'de engelliliğe ilişkin yapısal sorunları ortaya koymak amacıyla engelli çalışanlarını etkileyen belirleyicileri araştırmaktadır. Yazıcı vd. (2011) ise, engelli çalışanların sorunlarına odaklanan çalışmalarında 32 işyerinden, 421 engelli çalışan ve 31 işverene iki farklı anket yönlendirmişlerdir. Bulgular, yanlış algılamanın ve yetersiz destek araçlarının engelli istihdamının önündeki en yüksek bariyerler olduğunu göstermektedir. Genç ve Çat (2013) Kocaeli ili kapsamında, engellilerin istihdamı ve sosyal içerme ilişkisinin nitel ve nicel araştırma yöntemleriyle incelemiş olup, engelli bireylerin istihdamının gelir elde etme etkisi ile bireylerin aile kurma ve dolayısıyla sosyal entegrasyonunu arttırdığını belirtmektedirler. Arslan ve Altıntaş (2014), Türkiye'de engellilerin istihdam yoluyla toplumsal katılımını ele alan çalışmalarında, engellilere yönelik farkındalığı arttırarak olumsuz tutum ve davranışların kırılması, engelli istihdamı ve dolayısıyla toplumsal entegrasyonu arttırmayı amaçlayan bir uzman grubunun bir nevi koçluk görevi üstlendiği bir model önerisi sunmaktadır. Çavuş ve Tekin (2015) ise, engelli istihdamına yönelik politika araçlarından biri olan korumalı işyeri uygulamasını ele almışladır. Çalışmanın bulguları, korumalı işyeri uygulamasının özellikle zihinsel engeli olan bireyler göz önünde bulundurulduğunda doğru bir yöntem olmadığı, farklı politika araçlarının bir arada kullanılması gerektiğini ortaya koymaktadır. Eren ve Aktel (2016) engelli istihdamı ve erişilebilirliği konusunu 1998-2015 Avrupa Birliği (AB) düzenli ilerleme raporlarını analiz ederek incelemiş olup, 2005 yılı sonrasında $A B$ ile paralel olarak engelli politikalarına sistematik olarak yer verildiğini belirtmişlerdir

\section{Metodoloji}

Türkiye'de emek piyasasında engelliliğe ilişkin bilgi ve algı düzeyi, iş yerinde erişilebilir uygulama ve uyarlamalar ile engelli çalışanların konumu ortaya konulması amaçlanmaktadır. Bu doğrultuda elde edilecek bulguların işyerinde entegrasyonun arttırılması için yol gösterici olabileceği esas alınmıştır. Çalışma, belirli bir standartlaştırma ve genelleme yapmaktansa özgüllük ve esneklik özelliğini sahip olmayı hedeflemiştir. Çalışmanın bu özelliği ise nitel yönelimle sağlanmıştır (Marshall ve Rossman, 2006).

Mevcut çalışma kapsamında yer alan ve araştırmacıların kişisel bağlantıları ile ulaştığı şirketlerden bireylerle görüşmeler gerçekleştirilmiştir. Dolayısıyla, çalışmada kartopu örneklemi uygulanmış olup veri doyum noktasına gelindiğinde görüşmeler durdurulmuştur. Francis vd. (2010) yapmış oldukları çalışmalarında veri doyum noktasına erişim için araştırmacıların kriter belirleyebileceğini ifade etmiştir. Bu çalışma başlangıç analizi olarak 10 görüşmenin yapılmasını ve durdurma analizi olarak da bu görüşmelerin ardından gelen üç ardıl benzer görüşmenin olması halinde verilerin doyum noktasına ulaşmış olduğunun varsayılabileceğini ifade etmiştir. Çalışmamızda da aynı kriterler benimsenmiş olup toplam 20 yarı yapılandırılmış derinlemesine nitel görüşme gerçekleştirilmiştir. Bu görüşmelerdeki sorular genel olarak açık uçlu olup bazı sorular çoklu yanıt seçeneği ile birden fazla olasılığın varlığına işaret etmektedir.

Bu çalışmanın görgül boyutu Türkiye'de İstanbul, İzmir, Tekirdağ, Manisa ve Bolu olmak üzere, beş ilde farklı sektörlerde faaliyet gösteren şirketler temel alınarak yarı yapılandırılmış derinlemesine nitel görüşmeler sonucunda yapılan içerik analizine dayanmaktadır. Çalışma kapsamında yer alan şirketlerin sektörel alanları bankacılık ve finans, sağlık, telekomünikasyon, uluslararası lojistik, spor kulübü, kamu kurumu, otomobil üreticisi, halı, mobilya ve tekstil üreticileri, medya, inşaat ve turizm, eğitim, demir ve orman ürünleri, kâğıt fabrikası, elektronik sistemler ve hizmettir.

\section{Bulgular}

Kamu ve özel sektörde faaliyet gösteren farklı şirketlerde çalışan, 20 kişiyle görüşmeler yapılmıştır. Katılımcılar arasında engeli olmayan bireyler dışında, engelli çalışan, engelli işveren de bulunmaktadır. Tablo 2'de görüldüğü üzere, katılımcıların çalıştığı şirketlerin, \%65'inin 250'den fazla çalışanı, \%15'inin 11-50 çalışanı, \%10'unun 1-10 çalışanı ve yine \%10'unun 51-250 arasında çalışanı bulunmaktadır. Bu doğrultuda en büyük şirketin çalışan sayısı 18.000 iken, en küçük şirketin ise beştir. Katılımcı şirketlerin \%80'i özel sektörde, 
\%20'si ise kamu sektöründe faaliyet göstermektedir. Bulgular şirket büyüklüğünün engelli erişilebilirliği uygulamaları üzerinde önemli bir etkisi olduğunu göstermektedir. Zira büyük ölçekli firmalar maliyet avantajları, kurumsal sosyal sorumluluk projeleri ile kota yöntemi, korumalı işyeri gibi engelli istihdam politikaları dolayısıyla engelli istihdamı ve erişilebilirlik konularında daha etkin rol oynayabilmektedir.

Tablo 2. Şirket Büyüklüğü

\begin{tabular}{lcc}
\hline Çalışan Sayısı & Dağılım & $\%$ \\
\hline $1-10$ & 2 & 10 \\
$11-50$ & 3 & 15 \\
$51-250$ & 2 & 10 \\
$>250$ & 13 & 65 \\
\hline
\end{tabular}

Engelli erişilebilirliği kavramı, kısaca "herkes için erişim" ile ifade edilmektedir. Şirkette erişilebilirlik düzenlemelerinin kuruluş aşamasında mı yoksa engelli çalışan istihdamında sonra ortaya çıkan gereksinimler doğrultusunda mı yapıldığı sorusu bilinç ve tutum ölçümü açısından esas arz etmektedir. Bilindiği üzere, istihdam sonrası yapılan düzenlemeler şirketlere zaman ve finansal olarak yüksek maliyetler de yüklemekte olup, kimi zaman ise sonradan bir düzenleme yapısal sebeplerle mümkün olamamaktadır. Tablo 3'te yer alan sonuçlar, görüşülen şirketlerin yarısından fazlasının (\%55) engelli birey istihdamında sonra oluşan özel gereksinimlere göre makul düzenlemeler yapıldığını, şirketlerin \%25'inde işyerlerini kurarken erişilebilirliği düşündüğünü ve dört şirketin ise erişilebilirliği hususunu odak dışı bıraktığını göstermektedir. Görüşme sonuçları, göreceli olarak daha büyük firmaların erişilebilirlik için daha hızlı çözümler üretmek için istek ve kabiliyetine sahip olduğunu ortaya koymaktadır. Küçük ölçekli firmalarda ise ancak bireysel farkındalık veya engelli yakını olması erişilebilirliğin dikkate alınmasında etkili rol oynamaktadır. Bu firmaların, erişilebilirlik maliyetleri veya erişilebilir olmama nedeniyle engelli istihdamını tercih etmediği görülmektedir.

Tablo 3. Engelli Erişilebilirliği Düzenlemeleri

\begin{tabular}{lcc}
\hline Yanıt & Dağılım & $\%$ \\
\hline Erişilebilirlik şirketin kuruluş aşamasında & 5 & 25 \\
gerçekleştirilmiştir. & & \\
Erişilebilirlik, engelli birey istihdamından sonra dikkate & 11 & 55 \\
alınmıştır. & 4 & 20 \\
Erişilebilirlik göz önünde bulundurulmamıştır. &
\end{tabular}

Tablo 4'te belirtildiği üzere görüşülen firmaların \%81,75'i belirli birimlerinde erişilebilir bir tasarım uygulamaktadır ve sadece üç şirket tüm şirketin tamamen erişilebilir olduğunu belirtmektedir. Birim bazında erişilebilirliğin var olduğunu belirten şirketler daha ziyade restoran, kafeterya, tuvaletler gibi ortak alanlar ile idari birimlerde (pazarlama vb.) engelsiz tasarımlar bulunduğunu belirtmiştir. Şirketlerden biri ise yalnızca şirket girişinin erişilebilir olduğunu belirtmektedir. Devlet kurumlarından katılımcılar ise yalnızca sosyal hizmet binalarının erişilebilir olduğunu, zira binaların ve altyapının erişilebilir çözümler uygulamak için çok eski olduğunu ifade etmişlerdir. Bulgular, engelsiz tasarımı çoğunlukla idari alanlarda ve operasyonel birimlerde uyguladıklarını, hiçbirinde üretim biriminin erişilebilir olmadığını göstermektedir. Bu duruma gerekçe ise, üretim birimlerinin engelli bireyler için erişilebilir olmadığı veya engelli çalışan için iş güvenliği sorunu yaratabileceği yönünde toplanmaktadır. Buna ek olarak, özellikle yasal yükümlülükler ve cezalar nedeniyle, yeni kurulan şirketler tüm şirkette erişilebilirliğe odaklanmaktadır. 
Tablo 4. Engelsiz-Erişilebilir Tasarım

\begin{tabular}{lcc}
\hline Yanıt & Dağılım & $\%$ \\
\hline Şirketin farklı birimleri (satış, idari, üretim, ortak alan vb.). & 13 & 81,25 \\
Şirketin tamamında & 3 & 18,75 \\
\hline
\end{tabular}

Öncelikle görüşme süresince, kişilerin neredeyse tamamının "erişilebilirlik" kavramından anladıklarının, fiziki alt yapı erişilebilirliği ile kısıtı olduğu anlaşılmıştır. Bu doğrultuda görüşmede, erişilebilir uygulamalar ile makul düzenlemelerin aslında iletişim ve bilgi teknolojilerine erişimi de kapsadığı belirtilerek görüşmeye devam edilmiştir. İzleyen soruda tablo.5'te yer aldığı üzere cevapların çoğu $(\% 65,38)$, rampa, asansör, ışıklandırma, geniş kapı aralığı, sarı şeritler, engelli otoparkı vb. erişilebilir uygulamaların farklı ölçülerde dikkate alındığını belirtmektedirler. Erişilebilir uygulamaların kısıtlı olduğu ya da hiç olmadığını belirten katılımcılar, engelli çalışan olmadığı, fiziki/alt yapı erişilememe sorununun maliyet gerektirdiği veya fiziki alt yapıdan kaynaklanan özellikler nedeniyle yapılamadığı durumların (tekerlekli sandalyenin kullanımına uygun asansör genişliği gibi) bulunduğu gibi gerekçeler belirtmektedirler. Bilgi teknolojilerinin dikkate alındığını belirten katılımcı aynı zamanda kurumda iletişim engellerinin ve alt yapının da dikkate alındığını ifade etmiştir. Bilgi teknolojilerinde erişilebilirliği dikkate alan kurumlar bilişim teknolojileri ve telekomünikasyon alanında faaliyet gösteren şirketlerdir. Katılımcıların tamamı kolay uygulanabilir ve düşük maliyet gerektiren uygulamalara ağırlık verildiğini, bu gibi uygulamaların da daha ziyade ihtiyaç oluştuğunda yapıldığını vurgulamaktadır.

Tablo 5. Engelli Erişilebilirliği Uygulamaları

\begin{tabular}{lcc}
\hline Yanıt* & Dağılım & $\%$ \\
\hline Altyapı/fiziki çevre & 17 & 65,38 \\
Iletişim engelleri & 6 & 23,8 \\
Bilgi teknolojileri engelleri & 3 & 11,54 \\
\hline *çoklu yanıt & &
\end{tabular}

Kurumda engellilikle ilgili konularda veya engelli personele ilişkin konularla ilgili doğrudan bir sorumlu kişi veya birimin varlığı, iş yerinde engelli bireylere olan tutumun önemli bir göstergesidir. Tablo 6'da çoklu yanıta olanak veren görüşme sonuçları, KOBi'lerde şirket sahibi veya yöneticinin, engellilikle uğraşırken, büyük işletmelerde birden fazla kişinin/departmanın bu sorumluluğu paylaştığını ortaya koymaktadır. Katılımcılardan yalnızca biri kurumda, yasal temsilcinin engellilik meseleleriyle ilgilendiğini belirtmektedir. Bir diğer kurumda ise, iK Müdürü ve İş Sağlığı ve Güvenliği Birimi ile Engelli Birimi birlikte sorumlu olup, koordineli bir şekilde çalışmaktadır. Diğer seçeneği tercih eden görüşülen kişilerin beşi, engelli insanlarla belirli bir birim veya kişinin sorumlu olmadığını ancak gerekli olursa müdürün ilgileneceğini belirtmektedir. Buna ek olarak, devlet kurumlarından katılımcılar, engelli çalışandan ve engellilik konularından bağlı sosyal hizmetler müdürlüğünün sorumlu olduğunu belirtmektedir.

Tablo 6. Engellilik veya Engelli Personelle İlgili Kişi/Birim

\begin{tabular}{lcc}
\hline Yanıt* & Dağılım & $\%$ \\
\hline Müdür & 5 & 22,73 \\
İnsan Kaynakları Müdürü & 5 & 22,73 \\
Yasal Temsilci & 1 & 4,55 \\
İş Sağlığı ve Güvenliği Birimi & 3 & 13,64 \\
Hiçbiri & 1 & 4,55 \\
Diğer & 7 & 31,82 \\
\hline *çoklu yanıt & &
\end{tabular}


İzleyen görüşme sorularıyla bireylerin engellilik ve erişilebilirlikle ilgili bilgi ve farkındalık düzeyi ile konuya ilişkin hangi alanlarda bilgi sahibi olmak istedikleri ortaya koyulmaya çalışılacaktır. Bu amaçla, son beş yıl içinde kişinin kendisinin veya kurumda çalışan başka bir iş arkadaşının engellilik konusunda bir eğitime katılıp katılmadığı ve eğer katılım sağlandıysa konunun ne olduğu sorulmuştur.

Tablo 7. Engellilik ve Erişilebilirlikle ilgili Eğitime Katılım

\begin{tabular}{lcc}
\hline Yanıt & Dağııı & $\%$ \\
\hline Evet & 9 & 45 \\
Hayır & 11 & 55 \\
\hline *çoklu yanıt & &
\end{tabular}

Tablo 8' e göre, görüşülen bireylerden yalnızca biri kendi isteği doğrultusunda işaret dili eğitimi aldığını belirtmiş olup, diğer katılımcılar kurumdaki pozisyonları veya görev gereği kurum içi bilgilendirme eğitimi aldıklarını belirtmektedirler. Eğitim alan katılımcılardan ikisi ise, engelli birey ve aynı zamanda yönetici pozisyonunda olup, engellilikle ilgili birçok eğitim faaliyetine katıldıklarını belirtmektedirler. Engellilik ve/veya erişilebilirlikle ilgili eğitime katılan katılımcıların dördü, fiziki altyapı/erişilebilir tasarım eğitimi/ç̧alıştayına, üçü işaret dili, ikisi ise genel bilgilendirme (şizofreni ve otizm sendromu) eğitimi aldıklarını belirtmektedirler. Yasal düzenlemeler ve finansal çözümler ilgili eğitime katılan kişiler ise işveren olup, şirket sahibi olarak bu konularda bilgiye intiyaç duyduklarını belirtmektedirler.

Tablo 8. Engellilik-Erişilebilirlik Eğitim Konusu

\begin{tabular}{lcc}
\hline Yanıt* & Dăı̆ım & $\%$ \\
\hline Genel Bilgi & 2 & 18,18 \\
Fiziki erişilebilir düzenlemeler & 4 & 36,36 \\
iletişim/işaret dili & 3 & 27,27 \\
Bilgi teknolojileri ve destek araçları & 0 & 0 \\
Yasal düzenlemeler & 1 & 9,09 \\
Teşvik/fon fırsatları & 1 & 9,09 \\
\hline *çoklu yanıt & &
\end{tabular}

Tablo 9, katılımcıların engelli erişilebilirliğine ilişkin önemli gördükleri hususların önem derecelerini (\%) belirtmektedir. Bulgular yenilikçi destek araçlarının arttırıması gereğinin önemini ortaya koymaktadır. Katılımcılara göre yasal düzenlemeler ve işaret dili ise ikinci sırada yer almaktadır. Yasal düzenlemenin önemine vurgu yapan katılımcıların hepsi şirket sahibi veya yönetici kademesinde çalışan olup, özellikle teşvik, sigorta pirimi, fonlar gibi mali destek araçları gibi konularda bilgi yetersizliği olduğunu belirtmişlerdir. Katılımcılardan biri ise "ayrımcılık" konusunun da sıralamaya eklenmesini belirtmiştir.

Tablo 9. Engelli Erişilebilirliği ile İlgili Önemli Konular

\begin{tabular}{lcc}
\hline Yanıt* & Dağııı & $\%$ \\
\hline Farkındalı̆̆ı artırmak & 9 & 22,5 \\
İşaret Dili & 6 & 15 \\
Mimari altyapı & 4 & 10 \\
İşyerinde inovasyon ve destek araçları & 9 & 22,5 \\
Engel Türleri & 6 & 15 \\
Yasal düzenlemeler & 6 & 15 \\
*çoklu yanıt & &
\end{tabular}


Görüşmeler, katılımcıların işyerinde engellilik ve erişilebilirlik konularında bilgi, farkındalık ve ilgi düzeylerinin; eğitim, yaş, cinsiyet gibi çevre gibi bireysel farklılıklar yanında kurumdaki görevleri ve çalıştıkları sektörden de etkilendiğini ortaya koymaktadır.

\section{Sonuç}

Türkiye'de engellilere yönelik düzenlemeler ve makul düzenlemeler kamu kurumları tarafından hazırlanmaktadır. Çalışma, Türkiye'de engelli erişilebilirliğine ilişkin algı ve uygulamaların, kamu ve özel sektörden 20 farklı kişiyle birebir derinlemesine görüşmeler vasıtasıyla ortaya koymayı amaçlamıştır. Engelliler için en önemli sorunlar; farkındalık, engellilere yönelik yanlış algı/tutumlar ile sadece fiziksel/altyapı erişilebilirliği değil aynı zamanda iletişim, destek araçları gibi diğer erişilebilirlik unsurlarında yetersizliklerdir. İşyeri erişilebilir olsa bile iş yerine ve işe erişim sorunları yaşanmaktadır. İşverenlerin ise, engelli bireylerin iş yerinde verimin ve etkinliğin düşüşüne yol açabileceği, kurum içi iletişim sorunlarının yaşanabileceği gibi olumsuz önyargı ve tutuma sahip oldukları görülmektedir. Bu doğrultuda bilindiği üzere kronik rahatsızlıklar gibi görünmeyen ya da hafif ortopedik engel grupları istihdamda öncelikle olarak tercih edilmektedir. Ayrıca Türkiye'de engelli istihdamını arttırmak üzere gereken yasal mevzuatın var olduğu ancak uygulamada yetersizlik gözlenmektedir. Zira hali hazırda uygulanan kota yöntemi dışında sigorta pirim destek yöntemi gibi finansal yöntemlerin işverenler tarafından yeterince bilinmediği görüşmelerde dikkati çeken bir diğer husustur. İstihdam kararında engelli bireylere öncelik veren veya engelli farkındalığı yüksek olan işverenlerin engelli tanıdıkları olduğu ya da engelli çalışanların iş verimine dair olumlu deneyime sahip oldukları görülmektedir. Çalışmada dikkati çeken bir diğer husus, engelli erişimi sağlayan veya bu konuda kurumsal sosyal sorumluluk projeleri olan firmalarda çalışan bireylerin engellilere yönelik daha fazla farkındalığa sahip olduklarını göstermektedir.

Ülkenin makroekonomik yapısı engelli bireylerin istihdam olanaklarını etkileyen en önemli husustur. Engelli bireylerin çok azı yüksek eğitime erişebilmekte olup, daha ziyade başta hizmet sektörü olmak üzere niteliksiz ve düşük ücretli işlerde istihdam edilmektedir. İşyerine engelli bireylerin daha fazla entegrasyonu için engelli bireylerin öncelikle fiziki erişimini sağlamak, istihdam gerçekleştikten sonra ise işyerinde esnek iş modeli, korumalı işyeri gibi iş kapsamında düzenlemeler yapmak işgücü piyasasına katııı oranlarını da arttıracaktır. Erişilebilir düzenlemelerin ve istihdam oranlarında olası artış, engelli bireylerin sadece emek piyasası değil, sosyal hayata entegrasyonu için de önem arz etmektedir.

İşyerinde engelli erişilebilirliği üzerine yapılan bu araştırma gelecekte engelli bireylerin istihdamını arttıracak politikalar ile makul düzenlemelerin etkinliğini gösteren vaka çalışmaları bu alandaki yazına önem veren hem politika yapıcılar hem de araştırmacılar için önemli katkılar sunacaktır.

\section{Son Notlar}

1. Bu çalışma, Avrupa Komisyonu tarafından 2017-1-AT01-KA202-034995 proje numarası ile inovasyon için işbirliği ve iyi uygulamaların değişimi KA-2 Stratejik Ortaklık Programı tarafından finanse edilen uluslararası bir projenin ön sonuçlarıdır.

\section{Kaynaklar}

Arslan, H., \& Altıntaş, G. (2014). Engellilerin çalışma yaşamına katıımını arttırarak toplumla kaynaşmalarını sağlamayı hedefleyen bir model önerisi. Çankırı Karatekin Üniversitesi Sosyal Bilimler Enstitüsü Dergisi, 5(2), 165-186.

Bricout, J. C., \& Bentley, J. K. (2010). Disability status and perceptions of employability by employers. Social Work Research, 4(2), 87-95.

Council of Europe, (2004). Accessibility: Principles and guidelines. Council of Europe Publishing. https://rm.coe.int/CoERMPublicCommonSearchServices/DisplayDCTMContent?documentld=09000016805a2a 24, (Erişim Tarihi: 10 Kasım 2018). 
Çavuş, Ö. H., \& Akay, T. (2015). Türkiye'de engellilerin istihdam yöntemi olarak korumalı işyeri. Dokuz Üniversitesi IiBF Dergisi, 30(1), 145-165.

Duff, A., Ferguson, J., \& Gilmore, K. (2007). Issues concerning the employment and employability of disabled people in UK accounting firms: an analysis of the views of human resource managers as employment gatekeepers. The British Accounting Review, 39(1), 15-38.

Erten, Ş., \& Aktel, M. (2016). Ulusal program ve düzenli ilerleme raporları çerçevesinde Türkiye'nin engelli politikaları. Süleyman Demirel Üniversitesi Iktisadi ve Idari Bilimler Fakültesi Dergisi, 21(4), 1275-1297.

European Disability Forum, (2018). European accessibility act. http://www.edf-feph.org/european-accessibility-act-1 (Erişim Tarihi: 12 Kasım 2018).

Eurostat (2014). Disability statistics- barriers to employment. https://ec.europa.eu/eurostat/statisticsexplained/pdfscache/34422.pdf (Erişim Tarihi: 12 Kasım 2018).

Francis, J. J., Johnston, M., Robertson, C., Glidewell, L., Entwistle, V., Eccles, M. P., \& Grimshaw, J. M. (2010). What is an adequate sample size? Operationalising data saturation for theory-based interview studies. Psychology and Health, 25(10), 1229-1245.

Genç, Y., \& Çat, G. (2013). Engellilerin istihdamı ve sosyal içerme ilişkisi, Akademik Incelemeler Dergisi. 8(1), 363-393.

Handicap International, (2006). Good practices for the economic inclusion of people with disabilities in developing countries: funding mechanisms for self-employment. Cornell University ILR School.

International Labour Organisation-ILO (2003). Statistics on the employment situation of people with disabilities: a compendium of national methodologies. Working Paper No.40. https://www.ilo.org/wcmsp5/groups/public/--dgreports/---integration/documents/publication/wcms_079120.pdf, (Erişim Tarihi: 12 Kasım 2018).

Kulkarni, M., Boehm, S. A., \& Basu, S. (2016). Workplace inclusion of persons with a disability: Comparison of Indian and German multinationals. Equality Diversity and Inclusion: An International Journal, 35(7/8), 397-414.

Lindsay, S. (2011). Discrimination and other barriers to employment for teens and young adults with disabilities. Disability and Rehabilitation, 33(15-16), 1340-1350.

Marshall, C., \& Rossman, G. B. (2006). Data collection methods. Designing Qualitative Research, 97-150.

Organization for Economic Co-operation and Development-OECD (2010). Sickness, disability, and work: Breaking the barriers. $\quad$ https://www.oecd.org/publications/sickness-disability-and-work-breaking-the-barriers9789264088856-en.htm (Erişim Tarihi: 12 Kasım 2018).

Peterson, P. A., \& Quarstein, V. A. (2009). Disability awareness training for professionals, Disability and Society, 23(1), 43-48.

Pope, D., \& Bambra, C. (2009). Has the disability discrimination act closed the employment gap. Disability and Rehabilitation, 27(20), 1261-1266.

Robinson, J. E. (2009). Access to employment for people with disabilities: Findings of a consumer-led project. Disability and Rehabilitation, 22(5), 246-253.

Shier, M., Graham, J. R., \& Marion, J. (2009). Barriers to employment as experienced by disabled people: A qualitative analysis in Calgary and Regina, Canada. Disability and Society 24, (1), 63-75.

Tufan, I. , Yaman, H., \& Arun, O. (2007). Disability in Turkey: suggestions for overcoming current problems. International Social Work, 50(6), 839-846.

Tufan, I. (2007). Status of the disabled people in Turkey: a theoretical approach to the perception of the disabled in Turkey. Disability and Rehabilitation, 29(2), 173-178.

TC Resmi Gazete, Başbakanlık Mevzuatı Geliştirme ve Yayın Genel Müdürlüğünce Yayınlar (2018). 4857 İ̧̧ Kanunu.

Türkiye Aile ve Sosyal Politikalar Bakanlı̆̆ı, Engelli ve Yaşlı Hizmetleri Genel Müdürlüğü (2011). İşgücü piyasasının özürlüler açısından analizi. Ankara.

Türkiye İş Kurumu (işKUR), (2017). İstatistik bültenleri. https://www.iskur.gov.tr/kurumsal-bilgi/istatistikler/ (Erişim Tarihi: 16 Aralık 2018).

Türkiye İstatistik Enstitüsü (TÜiK), (2011). Population and housing census. http://www.tuik.gov.tr/Start.do (Erişim Tarihi: 16 Aralık 2018).

United Nations, (2011). Disability and the millennium development goals: a review of the MDG process and strategies for inclusion of disability issues in millennium development goal efforts.

Yazıcı, B., Şişman, Y., \& Kocabaş, F. (2011). Determining the problems of disabled employees: A survey study conducted in Eskisehir, Turkey. Disability and Society, 26(3), 285-292. 
This Page Intentionally Left Blank 